Iğdır Üniversitesi Fen Bilimleri Enstitüsü Dergisi, 11(3): 2371-2379, 2021

Journal of the Institute of Science and Technology, 11(3): 2371-2379, 2021

Tarla Bitkileri / Field Crops

ISSN: 2146-0574, eISSN: 2536-4618

DOI: $10.21597 /$ jist.848401

Geliş tarihi / Received: 28-12-2020

Derleme Makalesi / Review Article

Kabul tarihi / Accepted: 08-04-2021

Atıf İçin: Köse M, Kardeş YM, 2021. Baklanın (Vicia faba L.) Besinsel İçeriği ve Tıbbi Açıdan Yaraları. Iğdır Üniversitesi Fen Bilimleri Enstitüsü Dergisi, 11(3): 2371-2379

To Cite: Kose M, Kardes YM, 2021. Nutritional Content and Medicinal Benefits of Faba Bean (Vicia faba L.). Journal of the Institute of Science and Technology, 11(3): 2371-2379

\title{
Baklanın (Vicia faba L.) Besinsel İçeriği ve Tıbbi Açıdan Yararları
}

\section{Melike KÖSE ${ }^{1 *}$ Yusuf Murat KARDEŞ ${ }^{1}$}

ÖZET: Bakla (Vicia faba L.), baklagiller familyası içerisinde en zengin protein içeriğine sahip olan bitkidir. Kuru tanesiyle hayvansal gıdalarla karşılanamayan protein oranını bitkisel gıda olarak karşılamaktadır. Bakla köklerindeki bakteri sayesinde havadaki serbest azotu toprağa bağlamaktadır ve yeşil gübre olarak da kullanılmaktadır. Aynı zamanda bakla çeşitli ürünlerle ekim nöbeti sistemine girerek verim artışına katkıda bulunmaktadır. Ayrıca yeşil aksamının hayvan yemlerine katılarak rasyon oluşturması gibi yararlarının yanı sıra tıbbi açıdan da oldukça faydası bulunmaktadır. Bu çalışmada bakla bitkisinin besinsel içeriği, içerdiği anti-besinsel bileşenler ve tıbbi katkıları değerlendirilmiştir. Yapılan araştırmalarda; baklanın zengin içeriği sayesinde tedavilere olumlu etkilerde bulunmasına rağmen içerdiği anti-besinsel maddelerden dolayı insan ve hayvan sağlığına olumsuz etkilerde de bulunmaktadır. Bu derlemede, baklanın tıbbi olarak önemi değerlendirilmiştir.

Anahtar Kelimeler: Baklagil, Bakla, Besinsel bileşenler, Anti-besinsel bileşenler

\section{Nutritional Content and Medicinal Benefits of Faba Bean (Vicia faba L.)}

ABSTRACT: Broad bean (Vicia faba L.) is the plant has richest protein content in the legume family. With its dry grain, it meets the protein ratio that cannot be met with animal foods as a vegetable food. Thanks to the bacteria on the roots of the broad bean, it fixation the free nitrogen in airborne to the soil and is also used as green fertilizer. At the same time, broad bean contribute to the yield increase by entering the rotation system with various products. In addition, the green part has many benefits in terms of medicine as well as its benefits such as rationing by adding to animal feed. In this study, the nutritional content, anti-nutritional components and medicinal additives of the broad bean were evaluated. In the researches; Although broad beans have positive effects on treatments thanks to its rich content, it also has negative effects on human and animal health due to the anti-nutritional substances it contains. In this review, the medical importance of broad beans was evaluated.

Keywords: Legumes, Faba bean, Nutritional components, Anti-nutritional components

${ }^{1}$ Melike KÖSE (Orcid ID: 0000-0001-5061-2441), Yusuf Murat KARDEŞ ${ }^{1}$ (Orcid ID: 0000-0001-7144-9612), Bilecik Şeyh Edebali Üniversitesi Ziraat ve Doğa Bilimleri Fakültesi Tarla Bitkileri Bölümü

*Sorumlu Yazar/Corresponding Author: Melike KÖSE, e-mail: kosemelike16@hotmail.com 


\section{GÍRIS}

Bakla (Vicia faba L.), Fabales takımının Fabaceae (kelebek çiçekliler) familyasının Vicia cinsine ait, böcekler (arılar) vasitasıyla \%40-50 dolaylarında yabancı döllenen, diploid yapıda ( $2 \mathrm{n}=12)$, ekonomik değeri yüksek bir baklagil bitkisidir (Karaköy ve ark., 2015). Baklagiller geçmişten günümüze insanlık tarafından temel gıda maddesi olarak kullanılmaktadır. $\mathrm{Bu}$ ürünler, özellikle gelişmekte olan ülkelerdeki düşük gelirli insan grupları arasında insan beslenmesinde önemli bir yer tutmaktadır. İyi bir protein, diyet lifi, nişasta (Osorio-Diaz ve ark., 2003), mineral ve vitamin kaynağıdırlar (Kutos ve ark., 2002). Yararlı besin etkileri ve düşük maliyetleri nedeniyle genellikle öğ̈̈nlerde tercih edilmektedirler. Ayrıca, baklagillerin günlük diyete dahil edilmesinin diyabet, koroner kalp hastalığı ve kolon kanseri gibi çeşitli metabolik hastalıkların kontrolünde ve önlenmesinde birçok yararlı fizyolojik etkiye sahip olduğunu bildirilmiştir (Tharanathan ve Mahadevamma, 2003). Buna bağlı olarak baklagiller tıbbi amaç içinde yaygın olarak kullanılmaktadır. Baklagiller içerisinde tıbbi bitki sıfatıyla da öne çıkan bakla (Vicia faba L.), Fabaceae (baklagiller) familyasına ait olup, familyaya adını veren tek yıllık baklagil bitkisidir.

Kültürü yapılan baklanın orijini geniş bir alanı kaplamakta olup, Batı'da Atlas Okyanusu' ndan, Doğu' da Himalayalar' a kadar uzanmaktadır (Karaköy ve ark., 2017). Bu kadar geniş alana hitap eden baklanın adaptasyon kabiliyetinin yüksek olması birçok ülkede yetiştiriciliğinin yapılmasına olanak sağlamıştır. Dünya çapında yaklaşık 2.5 milyon ha alanda yetiştiriciliği yapılan bakla, 873 bin ha ekim alanı ile en fazla Çin'de yetiştirilmektedir (FAO, 2018). Türkiye'de ise bakla 4.3 bin ha' lık ekim alanına sahip olup, en fazla Batı Marmara Bölgesi ve Ege Bölgesinde yetiştirilmektedir (TÜİK, 2019). Üretim açısından bakla; kuru fasulye, bezelye ve nohuttan sonra Dünya' da dördüncü, Avrupa' da ise ikinci sırada yer almaktadır (İdikut ve ark., 2018). Avrupa' da daha çok hayvan beslemede kullanılan bakla, gelişmekte olan ülkelerde en çok insan gıdası olarak kullanılmaktadır. Hem Türkiye' de hem de birçok Afrika ve Asya ülkelerinde taze bakla, bakla konservesi ve çeşitli yemeklerde yaygın olarak kullanılmaktadır.

Bakla, Dünya'nın farklı yerlerinde çoğunlukla insan gıdası ve hayvan yemi olarak kullanılsa da tıbbi açıdan da çok önemli bir yere sahiptir. Bakla tüketimi kanser, kalp, böbrek, karaciğer, oküler algılama ve nörodejenarif hastalıklar (Parkinson, Alzheimer vb.) gibi hastalıklara yakalanma oranını azaltmakta ve mevcut hastalıkların ilerlemesini önlemektedir (Duc, 1997; Crépon ve ark., 2010; Köpke ve Nemeck, 2010). Tibbi değerinin, içeriğindeki polifenollerden ve yüksek antioksidan aktivitesinden kaynaklandığı düşünülmektedir (Ramos, 2007).

\section{Besinsel İçeriği}

Bakla besinsel değeri yüksek bir gidadır. Yüksek protein ve karbonhidrat ihtiva etmelerinden dolayı insanlar için temel gıda konumundadır. Bakla muhteviyatında besinsel bileşenlerin yanı sıra anti-besinsel bileşenlerde içermektedir. Bazı besinsel bileşenler ve değerleri Çizelge 1'de verilmiştir.

Besinsel bileșenler;

Baklanın karbonhidrat içeriği \%42-56 arasında değişiklik gösterdiği tespit edilmiştir (TÜRKOMP, 2020). Şeker, nişasta ve lif gibi polisakkaritlerden oluşan karbonhidratlar, tüketildiğinde vücuda büyük ölçüde enerji veren besin maddeleridir. Baklagillerde bol miktarda bulunan karbonhidratlar sindirilmesi zor maddelerdir. Gıda olarak tüketilecek baklagillerin basınç altında pişirilmesi sindirimi kolaylaştırıcı bir işlemdir. Baklagillerin besin değeri üzerine yapılan bir çalışmada, baklada \%3.1-7.1 şeker oranı, \% 41.2-52.7 nişasta oranı ve \% 8 lif oranı saptanmıştır (Reddy ve ark., 1984). Nişasta içermeyen polisakkarit olarak bilinen diyet lifinin büyük çoğunluğu baklanın tohum kabuğunda yer almaktadır. Lif tüketiminin az olması bazı bağırsak ve kalp 
rahatsızlarına yol açmaktadır. Diyet lifleri; çözünür ve çözünür olmayan diyet lifi olarak iki alt gruba ayrılmaktadır. Baklanın bileşimi ve beslenme karşıtı faktörleri üzerine yapılan bir çalışmada; toplam lif \%13.8 oranında belirlenirken; çözünür diyet lifleri \% 4.74 oranında, çözünür olmayan diyet lifleri ise \%9.07 oranında belirlenmiştir (Millar ve ark., 2019). Çözünür diyet lifleri bağırsak sağlığını olumlu etkilerken, çözünür olmayan diyet lifleri kandaki kolesterolün düşürülmesine ve kalp sağlığının korunmasına yardımcı olmaktadır (Burdurlu ve Karadeniz 2003; Pekşen ve Artık, 2005).

Çizelge 1. Baklanın Besinsel İçeriği

Kimyasal İçeriği

Karbonhidratlar

Proteinler

Toplam Yă̆ (Lipit)

Diyet Lif

Vitaminler

Mineraller

İz Elementler
Mevcut Miktarı ve Türü

$\% 42-56$
$\% 15-28$
$\% 1.26-1.96$
$\% 12.50-16.28$

A, B, C ve K Vitaminleri

$\mathrm{Ca}, \mathrm{K}, \mathrm{Na}, \mathrm{Mg}, \mathrm{P}, \mathrm{S}$

Kaynak: TÜRKOMP (Ulusal Gıda Kompozisyon Veri Tabanı) (2020)

İçeriğinde nişasta bulundurmasının yanı sıra protein açısından da oldukça zengin olan bakla, gelişmemiş ve gelişmekte olan ülkelerde hayvansal gıdaların maliyetinin yüksek oluşu nedeniyle karşılanamayan proteinin, düşük maliyetle bitkisel yolla karşılanmasına olanak sağlamaktadır. Baklanın protein oranı Çizelge 1' de gösterildiği gibi \% 15-28 arasında değişiklik göstermektedir (TÜRKOMP, 2020). Bakla içerdiği \% 28 oranında protein ile et ve balıktaki protein içeriğine yakın değerlere sahiptir (Prabhu ve Rajeswari, 2018; Millar ve ark., 2019). Bu nedenle de bazı ülkelerde "fakir adamın eti" olarak nitelendirilmiş bir bitkidir (Frühbeck ve ark., 1997; Macarulla ve ark., 2001). Baklada protein oranı yetiştirme koşulları ve genetik yapıya göre farklılık göstermektedir (Hacıseferoğulları ve ark., 2003; Geren ve Altan, 2005). Bakla tohumlarında yă̆ içeriği \% 2'nin altında olup, oldukça düşük miktardadır. İçerdiği yağ kolesterol ihtiva etmediğinden, bakla tüketimi kalp sağlığını korumak açısından önemlidir. Baklanın besin değerlerinin belirlenmesi üzerine yapılan bir çalışmada da yağ oranının \% 1- 2.5 arasında değiştiği bildirilmiştir (Larralde ve Martinez 1991).

A, B, C ve K vitaminlerini içeren bakla özellikle B vitamini açısından zengindir. B vitaminleri türlerinden; Tiamin (B1), Riboflavin (B2), Niasin (B3), Piridoksin (B6), Folat (Folik Asit (B9)) vitaminlerine sahip olup farklı organ aktivitelerinde destekleyici role sahiptir (TÜRKOMP, 2020).

Vitaminlere ek olarak; Al, B, Ba, $\mathrm{Co}, \mathrm{Cr}, \mathrm{Cu}, \mathrm{Fe}, \mathrm{Ga}, \mathrm{Li}, \mathrm{Mn}, \mathrm{Ni}, \mathrm{Pb}, \mathrm{Sr}, \mathrm{Zn}$ gibi mikro besin maddelerine (iz elementlere) de sahiptir. $V$. faba bu iz elementlerden özellikle demir (Fe) içeriğiyle öne çıkmaktadır (TÜRKOMP, 2020). Fe eksikliği genelde bebeklerde, hamile kadınlarda ve menstrüasyon dönemine girmiş kadınlarda sık görülmektedir. Fe eksikliği insanlarda anemiye neden olmaktadır. Bakla tüketen insanlarda Fe emiliminin artı̆̆̆ saptanmıştır. İçeriğindeki fitaz (fitik asidi parçalayan enzim), demir biyo-yararlılığını sağlayarak demir eksikliğinden muzdarip hastaların tedavisinde ek gida olarak kullanılmaktadır (Luo ve Xie, 2012).

Birçok besin içeriğinin yanında bakla stres koşullarında c-aminobutirik asit (GABA) sentezleyerek bir çeşit sinyal mekanizması oluşturur ve nöronlar arası iletişimi sağlayan nörotransmitter görevi görüp, sinir sistemi arası etkileşim kurarak bitkide stresin yol açabileceği olumsuzlukları azaltmaya çalışır. Bu durum insan sağlı̆ğ içinde oldukça önemlidir. GABA içeren bakla tüketildiğinde stres durumunda artan kan basıncı, kalp atış hızı, ağrı ve endişe gibi durumlarını 
hafifleterek dengelemeye yardımcı olur. Ayrıca GABA baklagillerdeki beslenme karşıtı faktörlerin yapısını değiştirerek etkilerini azaltmaktadır (Yang ve ark., 2013).

Anti-besinsel bilessenler;

Bakla içeriğinde beslenme üzerinde olumsuz etkisi olan anti-besinsel bileşenler de bulunmaktadır. $\mathrm{Bu}$ anti-besinsel maddeler; proteaz inhibitörleri (tripsin ve kimotripsin), oligosakkaritler, fenolik bileşikler, fitik asitler, siyanogenetik glikozitler (HCN), saponinler, lektinler ve vicine-convicinelerdir (Pekşen ve Artık, 2005).

Proteaz enzim inhibitörlerinden tripsin ve kimotripsin, protein parçalama işlevi gören enzimlerin işlevlerini ve protein sindirimlerini engellemektedirler. Bakla, \% 59'luk bir oranla diğer baklagil türlerine göre daha düşük bir sindirilebilirliğe sahiptir. Bunun nedeni ise tripsin inhibitörlerinin varlı̆̆ ile açıklanmaktadır (Pekşen ve Artık, 2005). Proteaz enzim inhibitörleri üzerine yapılan bir çalışmada ilk kez baklada proteaz enzim inhibitörü saptanmış (Learmonth, 1958), daha sonra soya ve bakla üzerine yapılan karşılaştırmalı çalışmalarda; soya tohumlarına kıyasla bakla tohumlarının daha düşük seviyede proteaz enzim inhibitörleri barındırdığı gözlenmiştir (Wilson ve ark., 1972; Warsey ve ark., 1974; Griffiths, 1979; Pekşen ve Artık, 2005). Proteaz inhibitörleri suda çözünebilen proteinler olduğundan suda kaynatıldığında yok olmaktadırlar.

Oligosakkaritler, birkaç monosakkaritin bileşiminden oluşan moleküllerdir. Bu bileşiklerin galaktoz içeren türleri (rafinoz, stakiyoz ve verbaskoz) insanlarda ve hayvanlarda gaz üretimini tetiklemektedir. Bakla; nohut ve fasulyeye oranla daha az oligosakkarit içermektedir (Pekşen ve Artık, 2005).

Fenolik bileşikler çoğunlukla bitkilerin çevresel etmenlere karşı ürettiği bir çeşit savunma mekanizmasıdır. Bu bileşikler bitkiye yarar sağlarken, insan tüketiminde bazı mineral maddelerin yararlanılabilirliğini kısıtlamaktadır. Fenolik bileşiklerden özellikle tanen, baklanın tohum kabuğu kısmında yoğunlaşmıştır (Ergün ve ark., 2002). Kanada'da yetişen düşük ve yüksek tanenli baklalar üzerinde yapılan çalışmada; baklanın \% 8-9 oranında tanen içerdiği bildirilmiştir (Akkad ve ark., 2019). Kondanse tanen içeriği yüksek bakla insanlarda ve hayvanlarda sindirimi olumsuz etkilediğinden, tanen içeriği düşük olan (zero tannin) baklalar beslenme için uygundur (Rolan ve ark., 2017). Tanen içeren gıdalar tüketildiğinde, buruk ve acımtırak bir tat vermektedir. Bu durum tanelerin haşlanması, kabuklarının soyulması gibi işlemlerle azaltılabilmektedir. Olumsuz etkilerinin yanı sıra kondanse tanenin hayvan beslenmesinde bazı faydaları da bulunmaktadır. Kondanse tanenler rumende bazı hidrojen üreten protozoalar ve doğrudan hidrojen kullanan metan üretici organizmaları engellediği ve sera gazı salınımını azalttığı bilinmektedir (Martin ve ark., 2016). Kondanse tanenler hayvan iç parazitlerini azaltmakta ve hayvanlarda verim artışı sağlamaktadır (Lüscher ve ark., 2016).

Fitik asitte fenolik bileşikler gibi minerallerin emilimini kısıtlayıcı maddedir. Baklada \%1.80 oranında bulunan fitik asit; kalsiyum, çinko, demir gibi minerallere bağlanarak minerallerin biyoyararlılığını azaltmaktadır (Reddy ve ark., 1982; Richardson ve ark., 1985; Doğan ve Bircan, 2009). Özellikle demir $(\mathrm{Fe})$ emilimini olumsuz etkileyerek, vücutta demir eksikliğinden kaynaklı anemiye neden olurlar (Koç ve ark., 2000). Olumsuz etkilerinin yanı sıra son zamanlarda yapılan çalışmalarda; fitik asidin antioksidan fonksiyonlara sahip olduğu ve koroner hastalıkları (kalp-damar hastalıkları) da önlediği bildirilmiştir (Febles ve ark., 2002).

Bazı baklagillerde özellikle çĭ̆ bakla tohumlarının kabuklarında siyanogenik glikozitler bulunmakta olup aktif siyanür kaynaklarıdır. Siyanogenetik glikozitlerin hidrolizi sonucu açığa çıkan HCN (Hidrosiyanik Asit) insan ve hayvan sağlığı açısından toksik bir maddedir (Liener, 1973). 
Yoğunlukla baklagillerde rastlanan saponinler, sulu çözeltilerde köpürme ve tatlarının acı oluşu gibi karakteristik özelliklere sahiptir. Saponin içeren gıdalar tüketildiğinde alyuvar yıkımı olarak bilinen hemolize neden olabilmektedir (Ertaş ve Bilgiçli, 2008).

Baklagillerde bol miktarda bulunan lektinlerin olumlu ve olumsuz özellikleri vardır. Olumlu özelliği alyuvarların pıhtılaşmasında katkı sağlamalarıdır. Olumsuz özelliği ise bağırsakların duvarlarına zarar vermeleridir. Bağırsaklar bu az zedelenmiş bölgeyi hücre yenileyerek eski haline kısa bir sürede döndürebilmektedirler. Fakat lektin içeren gıdaların sık tüketiminin yol açabileceği yoğun zedelenmeleri onaramazlar. Böylece bağırsaklarda emilim azalır ve yararlı maddelerin yanı sıra zararlı maddelerinde vücuda geçişlerine sebep olurlar (Pekşen ve Artık, 2005).

Vicine ve convicine; bir çeşit anemi türü hastalık olan favizm etmenleridir. Bu maddeler, glikoz6-fosfat dehidrojenaz (G6PD) enzimi eksik vücutlarda, alyuvarın yapısında değişikliğe neden olarak işlevlerini kaybetmelerine yol açar (Beutler, 1978).

$\mathrm{Bu}$ beslenme karşıtı faktörlerin olumsuz etkilerini azaltmak için çeşitli işlemler uygulanmaktadır. $\mathrm{Bu}$ işlemler tohum kabuğunu ayırma, öğütme, sslatma, haşlama, çimlendirme, fermantasyon ve 1sıl işlemler gibi uygulamalardır (Pekşen ve Artık, 2005; Coda ve ark., 2015). Böylece anti-besinsel özelliği azalmış baklagillerden biyo-yararlanım arttırılabilmektedir.

\section{Tıbbi Katkıları:}

\section{Parkinson hastalığının tedavisindeki rolü;}

Parkinson, beyindeki özel bir bölgedeki nöronların tahrip olmasına bağlı olarak yeterince dopamin salgılanamaması sonucu oluşan bir hastalıktır. Çoğunlukla yaşlılarda görülmekle birlikte bulguları (belirtileri) titreme, hareketlerin yavaşlaması ve yapılamamasıdır. Hastalığın kökten tedavisi bulunmamaktadır. Bu yüzden semptomatik ilaçlar yani var olan semptomları (bulguları) düzeltmeye yönelik ilaçlar kullanılmaktadır. Bu ilaçlar, hastalık vücuttaki dopamin eksiliğine bağlı olduğundan dopamin seviyesini artırmaya yönelik ilaçlardır. Burada dopamin yerine L-dopa proteini kullanılmaktadır (Karataş, 2005).

Bakla bitkisi; dopaminin bir öncüsü olan Levodopa (L-3,4-dihydroxyphenylalanine (L-dopa)) bakımından zengin bir protein kaynağıdır. Topal ve Bozoğlu (2016), bazı bakla genotiplerinin L-dopa içeriklerinin belirlenmesi üzerine yaptıkları bir çalışmada; bakla yapraklarında $10.88-33.41 \mathrm{mg} \mathrm{kg}^{-1}$, çiçeklerinde 40.95-96.37 mg kg-1 ve meyvelerinde 4.16-54.29 $\mathrm{mg} \mathrm{kg}^{-1}$ L-dopa saptamışlardır. L-dopa potansiyel olarak hipertansiyon ve parkinson gibi hastalıkların tedavisinde ilaç olarak kullanılabilmektedir (Ray ve Georges, 2010).

Dopamin mümkün olan en düşük dozda, hastaların semptomlarını tamamen geçirmek yerine hastaların günlük hayatını idame ettirecek dozda kullanılması tercih edilmektedir. Bunun sebebi de çok hızlı bir şekilde 2-3 yıl gibi bir süre içerisinde dopaminin etkisizleşmesi söz konusudur. Bu yüzden mümkün olduğunca en geç dönemde ve en düşük dozda uygulanarak tedaviye ilave edilmektedir (Karataş, 2005).

L-dopa ağızdan alındığında beyne ulaşmadan önceki basamaklarda büyük bir oranı inaktive olmaktadır. Bundan dolayı beyne çok düşük miktarda L-dopa ulaşmaktadır. L-dopa' nın yarayışlılığını arttırmak için genellikle parçalanmasını önlemeye yardımcı bir madde olan karbidopa ile beraber kullanılmaktadır (Karataş, 2005).

Antioksidan özelliği;

Antioksidan bileşikler, serbest haldeki radikallerin neden olduğu hasarları önlemede etkin bileşiklerdir. $\mathrm{Bu}$ antioksidanlar serbest halde olan radikallerin amaçlarına erişmeden ve tepkimelere 
girmeden onları tutarak ya da serbest radikallerin tepkime zincirlerini kırarak, verecekleri hasarı önlemede aktif rol alırlar (Azzi ve ark., 2004; Ratnam ve ark., 2006).

Bakla bitkisi bol antioksidan ihtiva etmektedir. Bakla tüketimiyle vücuda antioksidan alımı gerçekleşir. Antioksidanlar olmadan, serbest radikaller vücutta tahribata neden olmaktadır. Antioksidanlar da bu oluşabilecek tahribatı önleyici konumundadır (Chaieb ve ark., 2011).

Bakla tohumlarında bulunan fenolik antioksidan aktivite ve L-dopa içeriği, 1s1 stresi ile birlikte kısa mikro dalga ışınlarına maruz bırakılarak uyarılabilmektedir. Sekiz gün süreyle 1sı stresine maruz bırakılan tohumlar üzerine yapılan bir çalışmada; fenolik içerikler, glikoz-6-fosfat dehidrojenaz gibi bileşiklerde artış gözlenmiştir. Bu işlemde L-dopa' da \%59 artış olurken, fenolik antioksidan bileşenlerde \% 700 artış olmuştur (Randhir ve ark., 2003). Böylece antioksidanlar savunma mekanizmasında rol almıştır.

Insanda sitomegalovirüse (cytomegalovirus (CMV)) karșl direnç faktörü;

CMV insanlarda enfeksiyon etkeni bir virüs olup, tükürük, dışkı, idrar, anne sütü, kan nakli gibi yollarla bulaşabilmektedir. Yaygın olarak immun (bağışıklık) sistemi zayıf insanlarda ve yeni doğanlarda sık görülen viral enfeksiyondur (Anonim, 2020). Sitomegalovirüs işitme kaybı, görme kaybı ve mental retardasyona (zekâ geriliği) yol açabilmektedir (Obut ve ark., 2019).

CMV'ye karşı direnç proteini olan pp-150 proteini saptaması için yapılan bir çalışmada PCR cihazı ve Dot Blot Hibridizasyon Yöntemi kullanılarak, beş bakla çeşidinden üçünün pp-150 proteini içerdiği tespit edilmiştir (Yan ve ark., 2010). Bu çalışma bakladan elde edilebilecek pp-150 proteininin bu virüs enfeksiyonuna karşı bir önlem niteliğinde kullanılabileceğini göstermektedir.

Anti-diyabetik etki;

Halk arasında şeker hastalığı olarak bilinen Diabetes mallitus, insan vücudunda pankreastaki beta hücrelerinden salgılanan bir hormon olan insülin hormonunun salgılanmasındaki bozulmaya bağglı endokrin hastalıktır. Bu hastalık ömür boyu devam etmekte olup; viral enfeksiyon, otoimmun hastalık, çevresel etmenler ve beslenme gibi nedenlerden kaynaklanabilmektedir. Antioksidanca zengin bakla tüketen kişilerde pankreas hücrelerinde gençleşme sağlayarak anti-diyabetik etki gösterir. Hastalık tamamen yok edilemese de kontrol altında tutulabilmesine yardımcı olur (Fatima and Kapoor,2006 ; Yang ve ark., 2006; Hussein , 2012).

Anti-kanserojen etki;

Bakladaki biyoaktif bileşenler anti-kanser aktivitesi için büyük öneme sahiptir. Bu biyoaktif bileşenlerden lektin, kanser hücrelerinin gelişimi ve yayılımında dolaylı yoldan etkili rol oynayan matriks metalloproteinaz (MMP) enzim ailesi aktivitesinde farklılaşmalar sağlayarak zayıflatırlar ve hastalığın ilerlemesini önlemede yardımcı olur. Özellikle de kolon (bağırsak) kanserinde olumlu etki göstermektedir (Jordinson ve ark., 1999; Lima ve ark., 2016).

Favizm etkisi;

Bakla tüketen kişilerde, hayati önem taşıyan bir enzim olan glikoz-6-fosfat dehidrojenaz (G6PD) adlı enzimin eksik olması veya yeterince aktif olmaması durumunda kişi bünyesinde alyuvarların yıkımına yol açarak hemolitik anemiye neden olabilir. Baklanın yol açtığı hemolitik anemiye halk arasında bakla alerjisi olarak adlandırılan "favizm" adı verilir. Erkeklerde favizm kadınlara göre daha sık görülmektedir. Ayrıca iki yaşın altındaki çocuklarda da favizm görülme ihtimali fazladır (Laosombat ve ark., 2006). Bu eksiklik hastaları sıtmaya yatkın hale getirebilmektedir. Eğer önlem alınamazsa ölümcül sonuçlar doğurabilmektedir. Bu nedenle G6PD enzimi eksik olan kişiler bakla ile beslenmeden kaçınmalıdır. 


\section{SONUÇ}

Bakla zengin besin içeriğiyle insan ve hayvan beslenmesinde kritik rol oynamaktadır. İçerdiği protein, lif, vitamin ve mineraller açısından günlük alınması gereken makro ve mikro besin ihtiyaçlarının karşılanmasında önemli rol oynar. Beslenmeye olumlu etki eden bu tür maddelerin dışında, beslenmeye olumsuz yönde etki eden maddelerde barındırdığından toksisiteye neden olabilmektedir. Ancak bu anti-besinsel maddeler çeşitli işlemler uygulanarak en az seviyeye indirgenebilmekte ve böylece bakladan biyo-yararlılık üst seviyeye çıkarılabilmektedir.

T1bbi olarak; Parkinson tedavisine katkıları, kolon kanserinde anti-kanser etkileri, şeker hastalığında anti-diyabetik etkileri, insanda CMV virüsüne karşı direnç sağlamaları ve yüksek antioksidan içeriği gibi birçok önemli faydaları vardır. Fakat G6PD enziminden yoksun insanlar için olumsuz bir etkisi olan favizm hastalığına neden olduğundan bu kişiler bakla tüketmemelidirler. Favizm faktörü haricinde hayati role sahip baklanın değeri yeterince bilinmemektedir. Bakla üzerine yapılmış çeşitli çalışmalarda büyük öneme sahip bir bitki olduğu kanıtlanmıştır. Baklada bulunan biyoaktif bileşenler izole edilerek, biyomedikal uygulamalarda daha fazla değerlendirilmelidir. Bakla ıslahı üzerine yapılacak çalışmalarda, baklanın bu özelliklerinin göz önüne alınarak ıslahının yapılması beklenmektedir.

\section{Çıkar Çatışması}

Makaleyi yazan yazarlar arasında herhangi bir çıkar çatışması bulunmamaktadır.

\section{Yazar Katkısı}

Melike KÖSE: Makaleyi yazdı, Yusuf Murat KARDEŞ: Makaleyi düzenledi.

\section{KAYNAKLAR}

Anonim, 2020. Sitomegalovirüs. Perinatal Tip Vakfi. http://www.perinatal.org.tr/sitomegalovirus . (Erişim Tarihi:27.12.2020)

Azzi A, Davies KJ, Kelly F, 2004. Free Radical Biology-Terminology and Critical Thinking. FEBS Letters, 558 (1-3): 3-6.

Beutler MD, 1978. In Hemolytic Anemia in Disorders of Red Cell Metabolism (Winrobe, M.M., ed.). Plenum, USA.

Burdurlu HS, Karadeniz F, 2003. Gıdalarda Diyet Lifinin Önemi. Gıda Mühendisliği Dergisi, 7 (15): 18-25.

Chaieb N, González JL, López-Mesas M, Bouslama M, Valiente M, 2011. Polyphenols Content and Antioxidant Capacity of Thirteen Faba Bean (Vicia faba L.) Genotypes Cultivated in Tunisia. Food Research International, 44 (4): 970-977.

Coda R, Melama L, Rizzello CG, Curiel JA, Sibakov J, Holopainen U, Sozer N, 2015. Effect of Air Classification and Fermentation by Lactobacillus Plantarum VTT E-133328 on Faba Bean (Vicia faba L.) Flour Nutritional Properties. International Journal of Food Microbiology, 193: 34-42.

Crépon K, Marget P, Peyronnet C, Carrouée B, Arese P, Duc G, 2010. Nutritional Value of Faba Bean (Vicia faba L.) Seeds for Feed and Food. Field Crops Research, 115 (3): 329-339.

Doğan G,Bircan R, 2009. Bitkisel Yem Hammaddelerinde Bulunan Antibesleyici Faktörler ve Balıklar Üzerine Etkileri. Journal of Fisheries Science, 3 (4): 323-332.

Duc G, 1997. Faba Bean (Vicia faba L.). Field Crops Research 53 (1): 99-109.

Ertaş N, Türker S, Bilgiçli N, 2008. Çeşitli Proseslerin Baklagilin Besinsel ve Antibesinsel Öğelerine Etkisi. Türkiye, 10: 21-23.

Ergün A, Tuncer ŞD, Çolpan İ, Yalçın S, Yıldız G, Küçükersan MK, Küçükersan S, Önol AG, Muğlalı ÖH Şehu A, 2002. Yemler, Yem Hijyeni ve Teknolojisi. A.Ü. Veteriner Fakültesi, Hayvan Besleme ve Beslenme Hastalıkları Anabilim Dalı, Ankara, 465 s.

Fatima S, Kapoor R, 2006. In Vivo and In Vitro Glycemic Effects Of Certain Legumes. Journal of Food Science and Technology, 43 (3): 263-266.

FAO, 2018. Dünya Bakla Ekim Alanları, www.fao.org. (Erişim Tarihi:27.12.2020)

Febles CI, Arias A, Hardisson A, Rodriguez-Alvarez C, Sierra A, 2002. Phytic Acid Level in Wheat Flours. Journal of Cereal Science, 36 (1): 19-23. 
Frühbeck G, Monreal I, Santidrian S, 1997. Hormonal Implications of The Hypocholesterolemic Effect of Intake of Field Beans (Vicia faba L.) by Young Men with Hypercholesterolemia. The American Journal of Clinical Nutrition, 66 (6): 1452-1460.

Gajalakshmi S, Jeyanthi P, Vijayalakshmi S, Devi Rajeswari V, 2011. Phytochemical Constituent of Aconitumspecies-a Review. International Journal of Applied Biology and Pharmaceutical Technology, 2 (4): 121-127.

Geren H, Altan Ö, 2005. Ödemiş Koşullarında Yetiştirilen Bazı Bakla (Vicia faba var. major) Çeşitlerinin Hasıl Verimi ve Diğer Bazı Özellikleri Üzerinde Bir Araştırma. Ege Üniversitesi Ziraat Fak. Dergisi, 42 (1): 59-66 ISSN 1018-8851

Griffiths DW, 1979. The Inhibition of Digestive Enzyme by Extract of Field Bean (Vicia faba L.). Journal of the Science of Food and Agriculture, 32: 187-192.

Hussein MA, 2012. Anti-Inflammatory Effect of Natural Heterocycle Glucoside Vicine Obtained from Vicia faba L. Its Aglucone (divicine) Their Effect on Some Oxidative Stress Biomarkers in Albino Rats. Free Radicals and Antioxidants, 2 (2): 44-54.

İdikut L, Çabar YE, Zulkadir G, Çölkesen M, Çiftçi S, Karabacak T, 2018. Investigation of Distances Between Row on Two Faba Bean in Kahramanmaraş Conditions.1. International Gap Agriculture and Livestock Congress, 25-27 April 2018, Şanlıurfa.

Jordinson M, El-Hariry I, Calnan D, Calam J, Pignatelli M, 1999. Vicia faba Agglutinin, The Lectin Present in Broad Beans, Stimulates Differentiation of Undifferentiated Colon Cancer Cells. Gut, 44 (5): 709- 714.

Karaköy T, Demirbaş A, Yörük V, Toklu F, Baloch FS, Durukan H, Öztürk M, Ton A, Anlarsal AE, Özkan H, 2015. Türkiye Orijinli Bakla (Vicia faba L.) Genotiplerinin Soğuğa Dayanıklılık Yönünden İncelenmesi Üzerine Bir Araştırma, 11. Tarla Bitkileri Kongresi 7-10 Eylül, Çanakkale, Cilt:1, 430-433.

Karaköy T, Demirbaş A, Toklu F, Karagöl ET, Uncuer D, Gürsoy N, Özkan H, 2017. Ülkemizin Farklı Bölgelerinden Toplanan Bakla (Vicia faba L.) Yerel Popülasyonlarının Agronomik ve Morfolojik Karekterizasyonu. KSÜ Doğa Bilimleri Dergisi, 20: 356-361.

Karataş Y, 2005. Parkinson Hastalığının Tedavisi. Türkiye Klinikleri Dahili Tıp Bilimleri Dergisi, 1 (44): 6775.

Koc A, Kösecik M, Vural H, Erel O, Ataş A, Tatli MM, 2000. The Frequency and Etiology of Anemia among Children 6-16 Years of Age in The Southeast Region of Turkey. The Turkish Journal of Pediatrics, 42 (2): $91-95$.

Köpke U, Nemecek T, 2010. Ecological Services of Faba Bean. Field Crops Research, 115 (3): 217-233.

Kutos T, Golob T, Kac M, Plestenjak A, 2003. Dietary Fibre Content of Dry and Processed Beans. Food Chem, 80: 231-235

Laosombat V, Sattayasevana B, Chotsampancharoen T, Wongchanchailert M, 2006. Glucose-6-Phosphate Dehydrogenase Variants Associated with Favism in Thai Children. International Journal Of Hematology, 83 (2): 139-143.

Learmonth EM, 1958. The Influence of Soya Flour on Bread Doughs. III.-The Distribution of The Papain-İnhibiting Factor in Soya-Beans. Journal of the Science of Food and Agriculture, 9(5): 269-273.

Liener IE, 1973. Toxic Factors in Protein Foods. NATO Adv Study Inst on the Chem Biol \& Phys of Proteval, Reading, Eng, 1972. Proteins in Human Nutrition.

Lima AIG, Mota J, Monteiro SAVS, Ferreira RMSB, 2016. Legume Seeds and Colorectal Cancer Revisited: Protease İnhibitors Reduce MMP-9 Activity and Colon Cancer Cell Migration. Food Chemistry, 197: 3038.

Luo Y,Xie W, 2012. Effect of Phytase Treatment on Iron Bioavailability in Faba Bean (Vicia faba L.) Flour. Food Chemistry, 134 (3): 1251-1255.

Lüscher A, Suter M, Finn JA, 2016. Legumes and Grasses in Mixtures Complement Each Other Ideally for Sustainable Forage Production. The Journal of the International Legume Society, 12: 8-10

Macarulla MT, Medina C, De Diego MA, Chavarri M, Zulet MÁ, Martínez JA, Portillo MP, 2001. Effects of the Whole Seed and a Protein Isolate of Faba Bean (Vicia faba) on The Cholesterol Metabolism of Hypercholesterolaemic Rats. British Journal of Nutrition, 85 (5): 607-614.

Martin C, Copani G, Niderkorn V, 2016. Impacts of Forage Legumes on Intake, Digestion and Methane Emissions in Ruminants. Legume Perspectives, 12: 24-25.

Millar KA, Gallagher E, Burke R, McCarthy S, Barry-Ryan C, 2019. Proximate Composition and AntiNutritional Factors of Fava-Bean (Vicia faba), Green-Pea and Yellow-Pea (Pisum sativum) Flour. Journal of Food Composition and Analysis, 82: 103233. 
Obut M, Doğan Y, Bademkıran MH, Akgöl S, Kahveci B, Peker N, GülT, 2019. Diyarbakır İlindeki Gebe Kadınlarda Toksoplazma, Rubella ve Sitomegalovirus Seroprevalansı. Dicle Tip Dergisi, 46 (2): 189-194.

Osorio-Díaz P, Bello-Pérez LA, Sáyago-Ayerdi SG, Benítez-Reyes MDP, Tovar J,Paredes, López O, 2003. Effect of Processing and Storage Time on In Vitro Digestibility and Resistant Starch Content of Two Bean (Phaseolus vulgaris L.) Varieties. Journal of the Science of Food and Agriculture, 83 (12): 12831288.

Ouzounidou G, Ilias I, Giannakoula A, Theoharidou I, 2014. Effect of Water Stress and NaCl Triggered Changes on Yield, Physiology, Biochemistry of Broad Bean (Vicia faba) Plants and on Quality of Harvested Pods. Biologia, 69 (8): 1010-1017.

Pekşen E, Artık C, 2005. Antibesinsel Maddeler ve Yemeklik Tane Baklagillerin Besleyici Değerleri. Anadolu Tarım Bilimleri Dergisi, 20 (2): 110-120.

Prabhu SD,Rajeswari DV, 2018. Nutritional and Biological Properties of Vicia faba L.: A Perspective Review. International Food Research Journal, 25 (4): 1332-1340.

Ramos S, 2007. Effects of Dietary Flavonoids on Apoptotic Pathways Related to Cancer Chemoprevention. The Journal of Nutritional Biochemistry, 18 (7): 427-442.

Randhir R, Shetty K, 2003. Light-Mediated Fava Bean (Vicia faba) Response to Phytochemical and Protein Elicitors and Consequences on Nutraceutical Enhancement and Seed Vigour. Process Biochemistry, 38 (6): 945-952.

Ratnam VD, Ankola DD, Bhardwaj DK, Sahana MNV, Ravi K, 2006. Role of Antioxidants in Prophylaxis and Therapy: A Pharmaceutical Perspective. Journal of Control Release 113: 189-207.

Ray H, Georges F, 2010. A Genomic Approach to Nutritional, Pharmacological and Genetic Issues of Faba Bean (Vicia faba): Prospects for Genetic Modifications. Gentically Modified Crops and Food, 1 (2): 99106.

Reddy NR, Sathe SK, Salunkhe DK, 1982. Phytates in Legumes and Cereals. In Advances in Food Research Academic Press, 28: 1-92.

Reddy NR, Pierson MD, Sathe SK, Salunkhe DK, 1984. Chemical, Nutritional and Physiological Aspects of Dry Bean Carbohydrates-A Review. Food Chemistry, 13 (1): 25-68.

Richardson NL, Higgs DA, Beames RM, McBride JR, 1985. Influence of Dietary Calcium, Phosphorous, Zinc and Sodium Phytate Level on Cataract Incidence, Growth and Histopathology in Juvenile Chinook Salmon (Oncorhynchus tshawytscha). In: Francis G, Makkar, Harinder PS, Becker K, 2007. Antinutritional Factors Present in Plant-Derived Alternate Fish Feed Ingredients and Their Effects in Fis. Aquaculture 199: 197-227.

Roland WS, Pouvreau L, Curran J, Van de Velde F, de Kok PM, 2017. Flavor Aspects of Pulse Ingredients. Cereal Chemistry, 94 (1): 58-65.

Topal N, Bozoğlu H, 2016. Determination of L-dopa (1-3, 4-dihydroxyphenylalanine) Content of Some Faba Bean (Vicia faba L.) Genotypes. Tarım Bilimleri Dergisi, 22: 145-151

TÜİK, 2019. Türkiye Bakla Ekim Alanları, www.tuik.gov.tr. (Erişim Tarihi:27.12.2020)

Warsey AS, Norton G, SteinM, 1974. Protease Inhibitors from Broad Bean, Isolation and Purification. Phytochemistry, 13: 2481-2486.

TÜRKOMP (Ulusal Gıda Kompozisyon Veri Tabanı), 2020. Baklanın Besinsel İçeriği, http://www.turkomp.gov.tr/food-bakla-216.(Erişim Tarihi:27.12.2020)

Wilson BJ, McNab JM, Bently H, 1972. Trypsin Inhibitor Activity in The Field Bean (Vicia faba L.). Journal of the Science of Food and Agriculture, 23: 679-684.

Yan H, Li G, Gong W, Jiao H, Chen H, Ji M, 2010. Expression of Human Cytomegalovirus pp-150 Gene in Transgenic Vicia faba L. and Immunogenicity of pp-150 Protein in Mice. Biologicals, 38 (2): 265-272.

Yang R, Guo Q, Gu Z, 2013. GABA Shunt and Polyamine Degradation Pathway on $\gamma$-Aminobutyric Acid Accumulation in Germinating Fava Bean (Vicia faba L.) under Hypoxia. Food Chemistry, 136 (1): 152159. 